Mémoire.

\title{
DISTRIBUTION AND RELATIVE DENSITY OF PHLEBOTOMINE SANDFLIES (DIPTERA: PSYCHODIDAE) IN ROME, ITALY
}

\author{
C. KHOURY, C. CAVALLINI, N. MICELI, M. MAROLI
}

\begin{abstract}
SUMMARY
Using sticky traps, a total of $533(72.04 \%$ males $)$ phlebotomine sandflies were collected in urban and periurban areas of Rome during three consecutive sandfly seasons between 1987-1989. Five species were identified, 4 belonging to the genus Phlebotomus and one to the genus Sergentomyia. $P$. perniciosus $(87.80 \%)$ was the

more abundant species followed by $S$. minuta $(8.82 \%), P$. perfiliewi $(2.82 \%)$, P. mascittii $(0.38 \%)$ and P. papatasi $(0.18 \%)$. Some observations on the sandfly distribution in the urban area are discussed.

\section{RÉsumé : Distribution et densité relative des phlébotomes dans des zones urbaines et périurbaines de Rome, Italie.}

Cinq cent cinquante trois phlébotomes, dont $72,04 \%$ mâles, ont été capturés pendant une enquête entomologique utilisant les pièges adhésifs dans des zones urbaines et périurbaines de Rome. L'enquête a été effectuée par trois ans de suite, de 1987 à 1989 , pendant les mois chauds de juin à octobre. Cinq espèces ont été identifiées. Quatre appartenant au genre Phlebotomus et une au

genre Sergentomyia. $P$. perniciosus $(87.80 \%)$ a été l'espèce la plus abondante suivie par $S$. minuta $(8,82 \%), P$. perfiliewi $(2,82 \%)$, $P$. mascittii $(0,38 \%)$ et $P$. papatasi $(0,18 \%)$. La présence des différentes espèces des phlébotomes a été considérée par rapport à l'hétérogénéité des conditions de développement urbain des zones prospectées.
\end{abstract}

\section{INTRODUCTION}

Phlebotomine sandflies (Diptera: Psychoidae) are endemic in Italy. Seven species have been reported from different biotopes of continental Italy, Sicily and Sardinia (Biocca et al., 1977). Numerous studies on rural sandfly populations have been carried out (see Pampiglione and Bettini, 1981 for references), particularly in relation to the role of sandflies in the transmission of Leishmania (Bettini et al., 1986; Maroli et al., 1987; Maroli et al., 1988a).

In contrast, few studies have been carried out in the urban areas although it is known that sandflies were very abundant in Rome; Grassi, in an interview in "Messaggero » of 1905 (Castelli, 1905), named the sandflies « New invaders of Rome " since many people were forced to leave their homes in the centre of Rome because the nuisance caused by the high sandfly density. Two years later, the same author (Grassi, 1907) described, for the first time, the larval and pupal stages of Phlebotomus papatasi collected in cellars of the centre of Rome.

In the same habitat (cellars of via Panisperna in Rome), Grassi (1908) described a new species called $P$. mascittii. The presence of $P$. perfiliewi and Sergentomyia minuta is

Istituto Superiore di Sanità, Department of Parasitology, Viale Regina Elena 299, 00161 Rome, Italy.

Accepté le : 9 juillet 1992. also reported by Saccà (1941) and Jerace (1946), respectively, in urban and suburban areas of Rome.

Visceral, cutaneous and canine leishmaniasis are reported to be present in Rome (Fulci and Basile, 1911; Colarizi, 1935; Marchesi et al., 1935; Urso, 1941 ; Benetazzo and Tripodi, 1948).

The sandfly density in towns, nevertheless, could be affected by the increased urban pollution and/or by the disappearance of suitable breeding places (stables). Adler and Theodor (1931) reported that five sandfly species ( $P$. perniciosus, $P$. papatasi, $P$. major, $P$. sergenti and $S$. minuta) were most common at the periphery of the Catania, in the vicinity of stables and gardens, and rare in the urban centre. D'Alessandro et al. (1947) described a recrudescence of $P$. papatasi density in the city of Palermo (more than 3,000 specimens were caught inside houses), which was probably due to the new breeding and resting sites in the ruins caused by bombing.

More recently, Fausto et al. (1986), by using castor oiled papers in urban and peri-urban areas of Florence, collected 1,179 sandfly specimens belonging to $P$. perniciosus $(15.86 \%)$, $P$. perfiliewi $(0.93 \%) ; P$. major $(0.08 \%)$ and Sergentomyia minuta (83.12 \%). Maroli et al. (1990) found that three species, $P$. perniciosus $(73.6 \%), P$. perfiliewi $(1.9 \%)$ and $S$. minuta $(34.5 \%)$ are still present in urban areas of Palermo.

In the present note we report the results of a sandfly survey carried out in 16 areas of Rome during three consecutive sandfly seasons, from 1987 to 1989. 


\section{STUDY AREA}

The geographical distribution of the 16 collecting stations chosen for the sandfly survey in urban and peripheral localities of Rome is shown in the map of Figure 1. The localities, the methods used, the habitats investigated for sandfly collection and the probable vertebrate hosts at each station is given in Table I. All the stations were located inside the area limited by the motor-road « GRA », except station 16 (Casalotti). Nine out of 16 stations were crevices of dry walls or buttress. Some of the stations $(2,7,8,10$, $11,15)$ were located in roads with dense urban traffic. Stations 3, 5, 13, 14 were situated in parks and/or gardens and one of these (3) was a stable inhabited by horses, dogs and chickens. Station 1 was Rome Zoo situated in the centre of the city, close to Villa Borghese park. Station number 16 was in a urban area at the periphery of Rome. Stations 9 and 12 were two farms and station 4 was the Institut of Agriculture which also included a stable.

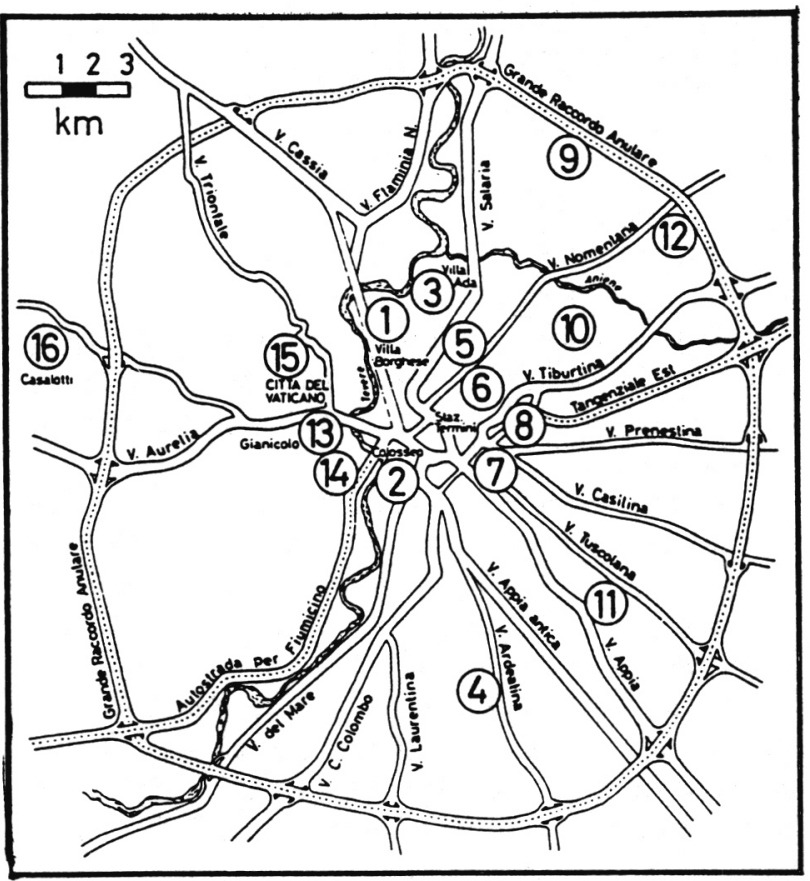

Fig. 1. - Distribution of the collecting stations in the urban and peri-urban areas of Rome. The names of the localities are reported in Table $I$.

\section{MATERIALS AND METHODS}

Two collecting methods were used: sticky papers and CDC light traps. A total of 2,686 castor oiled papers $(20 \times 20 \mathrm{~cm})$ were set during the three years. The number of sticky traps used in each station is given in Table I. To compare capture results at different localities the number of sandflies per square metre of oiled paper surface was calculated for each station. The density index
TABLE I. - Localities, methods used, habitats, probable hosts for each collecting station.

\begin{tabular}{|c|c|c|c|c|c|c|c|}
\hline \multirow[b]{2}{*}{$\mathrm{N}$. } & \multirow[b]{2}{*}{ Localities } & \multicolumn{2}{|c|}{ Methods } & \multirow{2}{*}{\multicolumn{2}{|c|}{ Habitat }} & \multirow{2}{*}{\multicolumn{2}{|c|}{ Hosts }} \\
\hline & & OP & $\mathrm{CDC}$ & & & & \\
\hline 1 & 200 & 178 & & Stable & & (1) & \\
\hline 2 & Roseto & 103 & & Buttress & crevice & gecko, r & rat \\
\hline 3 & Villa Ada & 150 & 8 & Stable & & $\begin{array}{r}\text { horse, do } \\
\text { chicken }\end{array}$ & $\begin{array}{l}o g, \\
n\end{array}$ \\
\hline 4 & Vigna Murata & 38 & 10 & $"$ & & $\begin{array}{l}\text { cow, dog, } \\
\text { fowl }\end{array}$ & \\
\hline 5 & villa Torlonia & 131 & & Buttress & crevice & gecko, $r$ & rat \\
\hline 6 & Viale Regina Elena & 29 & & $"$ & $"$ & $n$ & $"$ \\
\hline 7 & Porta S.Sebastiano & 137 & & " & $"$ & $"$ & $"$ \\
\hline 8 & Verano & 30 & & $"$ & $"$ & $n$ & $"$ \\
\hline 9 & Settebagni & 161 & & Stable & & sheep, d & dog \\
\hline 10 & Pietralata & 21 & & Buttress & crevice & gecko, $r$ & rat \\
\hline 11 & Appia Pignatelli & 87 & & $"$ & $n$ & $"$ & $"$ \\
\hline 12 & Nomentana & 370 & 8 & Stable & & $\begin{array}{l}\text { sheep, do } \\
\text { pig, fow }\end{array}$ & $\begin{array}{l}\log , \\
\text { wl }\end{array}$ \\
\hline 13 & Orto Botanico & 333 & & Buttress & crevice & gecko, $r$ & rat \\
\hline 14 & Villa sciarra & 138 & & $"$ & $"$ & $"$ & $"$ \\
\hline 15 & città del vaticano & 14 & & $"$ & $"$ & $"$ & $"$ \\
\hline 16 & Casalotti & 829 & 8 & Chicken $h$ & house & chicken & \\
\hline
\end{tabular}

$\mathrm{OP}=$ Number of oiled papers used $; \mathrm{CDC}=$ Number of light traps used.

(1) Oiled papers were set inside the shelters of steinbock, " girgentane " goats, antelopes, bantengs and gazelles.

was determined as reported by Biocca et al. (1977) and WHO (1979) namely: lower than $8 / \mathrm{m}^{2}=$ species present; between 8 and $32 / \mathrm{m}^{2}=$ medium density; more than $32 / \mathrm{m}^{2}=$ high density.

Due to the limited number of suitable localities, a low number of CDC light traps (total $=34$ ) were also used in 4 out of 16 stations (Table I).

The collecting period was from the middle of June to the end of October 1987-1989. During this three year capture period, stations $1,2,4,5,6,8,9,10,13,14,15$ were inspected 6 times, whereas stations $3,7,11,12,16$ were visited $11,9,9,20$ and 32 times, respectively. Sticky traps were left in situ for a minimum of 24 hours and a maximum of 48 hours.

The sandfly specimens were prepared as permanent mounts and identified as previously described (Maroli and Bettini, 1977).

\section{RESULTS AND DISCUSSION}

Sandflies were found in 10 out of 16 collecting stations surveyed. A total of 533 phlebotomines, $72.05 \%$ of which were males, were caught during the three years of survey. Five species were identified, 4 belonging to the genus Phlebotomus (perniciosus $87.80 \%$, perfiliewi $2.82 \%$, papatasi $0.19 \%$, mascittii $0.38 \%$ ) and one to the genus Sergentomyia (minuta $8.81 \%$ ). The species identified for each 
TABLE II. - Phlebotomine species caught during the sandfly seasons 1987-1989 in 10 localities of Rome.

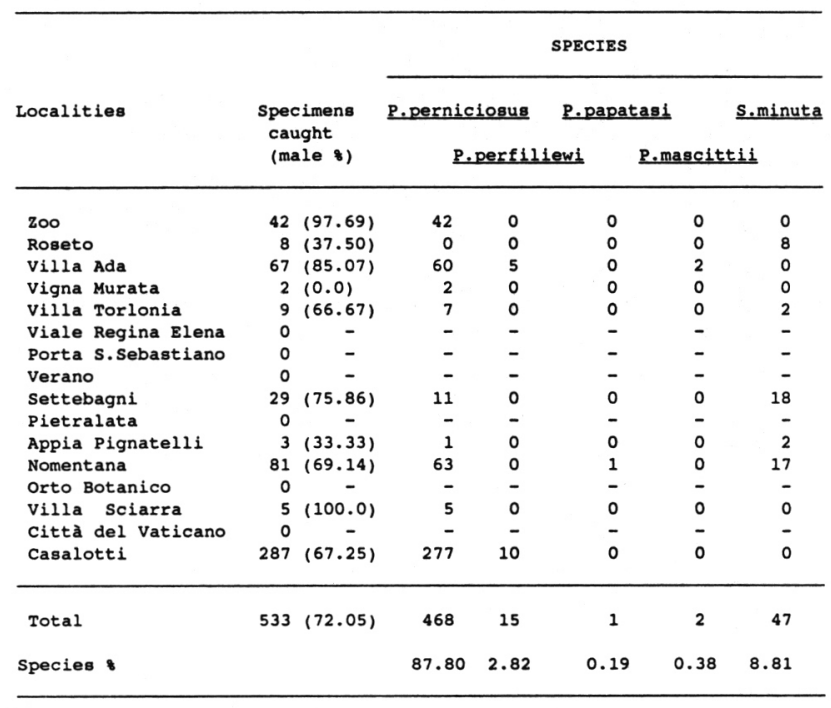

locality are reported in Table II. $P$. perniciosus was present in all the stations where sandflies were captured except station 2 (Roseto). $P$. perfiliewi was caught with CDC light traps only and it was present in two stations, namely Villa Ada and Casalotti. $P$. papatasi and $P$. mascittii were rare, one and two specimens being collected at Nomentana and Villa Ada respectively. $S$. minuta was present in 5 out of the 10 positive stations.

From our results it appears that in Rome, $P$. perniciosus is the most abundant species $(87.80 \%)$ and it is wide-spread in the area studied. The endophilic $P$. papatasi appears to be rare in contrast to the observations of Grassi (1905). These results could be explained by two hypotheses. The species could be rare because its density was lowered by the intradomestic use of DDT, as suggested by Biocca et al. (1977), or the collecting methods used and the habitats inspected were unsuitable to detect $P$. papatasi. However, this species has been caught in a village $30 \mathrm{~km}$ from Rome by using mouth aspirators. A total of $134 P$. papatasi $(90 \%$ of which females, freshly blood feed) were collected in one bedroom in the early morning (Maroli, 1988).

$P$. perfiliewi was collected in two localities by using CDC light traps only. Probably the species is more abundant and the habitats surveyed through the use of sticky traps are unsuitable resting places for the species. In 1979 a single specimen of $P$. perfiliewi was caught by one of us (M. M.) in a house near station 5, namely Villa Torlonia.

From our results it can be concluded that sandflies are still present in many areas of Rome. According to the density index reported in Materials and methods, sandflies are « present » in nine areas (Table III). However, such a " presence " is very low in areas with high urban pollution whereas it is of considerably higher in gardens, parks and in the zoo.
TABLE III. - Observed sandfly densities/sticky surface $\left(m^{2}\right)$ related to the total of specimens caught during the three years capture.

\begin{tabular}{llll}
\hline Localities & $\begin{array}{l}\text { Total sticky } \\
\text { surface } \\
\left(\mathrm{m}^{2}\right)\end{array}$ & $\begin{array}{l}\text { Number of } \\
\text { specimens } \\
\text { caugth }\end{array}$ & $\begin{array}{c}\text { Dengity/ } \\
\mathrm{m}^{2}\end{array}$ \\
\hline
\end{tabular}

\begin{tabular}{lrrl} 
Zoo & 7.12 & 42 & 5.89 \\
Roseto & 4.12 & 8 & 1.94 \\
Villa Ada & 6.00 & 31 & 5.16 \\
Villa Torlonia & 5.24 & 9 & 1.71 \\
Settebagni & 6.44 & 29 & 4.50 \\
Appia Pignatelli & 3.48 & 3 & 0.86 \\
Nomentana & 14.08 & 81 & 5.75 \\
Villa Sciarra & 5.52 & 5 & 0.90 \\
Casalotti & 33.16 & 269 & 8.11 \\
\hline
\end{tabular}

Acknowledgments. - The authors wish to thank Mrs. C. LEZzerini, Mrs. C. Giovannetti, Mr. M. Ricco and Dr. E. Perrotti who helped us in collecting sandflies.

\section{REFERENCES}

Adler S., Theodor O. : Investigation on Mediterranean Kala-azar. III. The sandflies of the Mediterranean basin. Distribution and bionomics of sandflies in Catania District. Proc. R. Soc. London B, 1931, 108, 464-480.

Benetazzo B., Tripodi T. : Due casi di leishmaniosi cutanea a Roma. Arch. Ital. Sci. Med. Colon. Parasitol., 1948, 19, 90-94.

Bettini S., Gramiccia M., Gradoni L., Atzeni M. C. : Leishmaniasis in Sardinia. II. Natural infection of Phlebotomus perniciosus Newstead, 1911, by Leishmania infantum Nicolle, 1908, in the province of Cagliari. Trans. Roy. Trop. Med. Hyg., 1986, 80, 458-459.

Biocca E., Coluzzi A., Costantini R. : Osservazioni sulla distribuzione dei flebotomi italiani e su alcuni caratteri morfologici differenziali tra le specie del sottogenere Phlebotomus (Larroussius). Parassitologia, 1977, 19, 19-31.

Castelli C. : I nuovi invasori di Roma. I flebotomi detti pappataci. Un'altra scoperta del Prof. Grassi. Il Messaggero, 1905.

Colarizzi A. : Osservazioni clinico-statistiche ed epidemiologiche sulla leishmaniosi in Roma. Policlinico Sez. Pratica, 1935, 42, 413-429.

D'Alessandro G., Burgio G. R., Mariani M. : Commento all'attuale recrudescenza della leishmaniosi viscerale a Palermo. Prospettive della lotta contro i flebotomi a mezzo di D. D. T. La Riforma Medica, 1947, 12, 256-259.

Fausto A. M., Maroli M. : Osservazioni sulla distribuzione delle specie di flebotomi in alcune zone urbane e periurbane di Firenze. Parassitologia, 1986, 28, 238.

Fulci F., Basile C. : Un caso di kala-azar a Roma. Pathologica, 1911, 3, 74.

Grassi G. B. : Ricerche sui flebotomi. Mem. Soc. ital. Sci. Nat., 1907, 14, 353-394.

Grassi G. B. : Intorno ad un nuovo Flebotomo. Atti Acc. Naz. dei Lincei Rc., 1908, 17, 681-682.

Jerace F. : Flebotomi nel Lazio (Presenza del Phlebotomus parroti, Adler e Theodor, 1927 nel suburbio di Roma). Ann. Ig., 1946, 56, 210-212.

Marchesi F., Crainz F., Scapaticci R. : La leishmaniosi dei cani a Roma (Ricerche compiute nella stagione invernale e primaverile). Boll. Atti Accad. Med. Roma, 1935, 60, 296-303.

Maroli M. : La specie Phlebotomus papatasi (Diptera : Psychodidae) è attualmente rara in Italia? Alcuni aspetti sanitari legati alla sua endofilia. Parassitologia, 1988, 30 (supl. I), 119-120. 
Maroli M., Bettini S. : Leishmaniasis in Tuscany (Italy): (I) An investigation on phlebotomine sandflies in Grosseto Province. Trans. Roy. Soc. Trop. Med. Hyg., 1977, 71, 315-321.

Maroli M., Gramiccia M., Gradoni L. : Natural infection of sandfly Phlebotomus perfiliewi with Leishmania infantum in a cutaneous leishmaniasis focus of the Abruzzi region, Italy. Trans. Roy. Trop. Med. Hyg., 1987, 81, 596-598.

Maroli M., Pampiglione S., Tosti A. : Cutaneous leishmaniasis in western Sicily (Italy) and preliminary survey of phlebotomine sandflies (Diptera: Psychodidae). Parassitologia, 1988, 30, 211-217.

Maroli M., Gramiccia M., Gradoni L., Ready P. D., Smith D. F., Aquino C. : Natural infection of phlebotomine sandflies with Trypanosomatidae in central and south Italy. Trans. Roy. Trop. Med. Hyg., 1988a, 82, 227-228.

Maroli M., Lavagnino A., Ansaldi G., Cavallini C. : Indagine sui vettori di leishmaniosi (Diptera, Psychodidae) in tre differenti ambienti della Sicilia occidentale e in due delle isole Eolie. Parassitologia, 1990, 32, 305-311.

Pampiglione S., Bettini S. : Bibliografia Italiana delle Leishmaniosi dalle origini al 1980. Ann. Ist. Sup. Sanità, 1981, 17, 1-150.

Saccà G. : Presenza in Italia del Phlebotomus larroussei Langeroni e Nitzulescu 1931 (Dipt. Psychodidae). Boll. Soc. Entomol. Ita., 1941, 19, 156-161.

Theodor O. : Die Fliegen der Palearktischen Region. Lief. 201. 9c, Psychodidae, Phlebotominae, E. Schweizerbort'sche Verlagsbuchhand lerung, 1958, 1-55.

Urso B. : Su di un caso di leishmaniosi cutanea osservato a Roma. Med. Trop. Subtrop., 1941, 1, 209-212.

WHO : Studies on leishmaniasis vectors/reservoirs and their control in the old world: part 1. Europe. WHO/VBC/79, 1979, 749. 